\title{
EVALUASI KUALITAS SKRIPSI DI JURUSAN PAI FITK IAIN SURAKARTA
}

\author{
Purwanto \\ Institut Agama Islam Negeri (IAIN) Surakarta \\ akupur@yaboo.com
}

\begin{abstract}
This study aimed to start an effort to evaluate the quality of thesis institutionally. The purpose of this study is to determine the quality of the thesis and determine the achievement of the quality of the thesis as a research work. This study is a descriptive evaluation. The study was conducted at the Department of PAI FITK IAIN Surakarta. The results showed several things. First, the majority of PAI student thesis in 2012 used qualitative research methods. Second, the quality of PAI student thesis in 2012 were generally good, on the thesis that uses quantitative and qualitative research methods. Third, the thesis uses quantitative research methods have a bigher quality index than the thesis that uses qualitative research methods. Fourth, for the thesis used quantitative research methods showing the low quality of the elements present in the background of the problem and framework of thinking. Fifth, for the thesis used qualitative research methods showing the low quality of the elements contained in the title of the study and background of the problem.
\end{abstract}

Keywords: Evaluation, Quality, Thesis

\begin{abstract}
Abstrak
Penelitian ini mendorong upaya merintis evaluasi kualitas skripsi secara kelembagaan. Tujuan penelitian adalah untuk mengetahui kualitas skripsi dan mengetahui pencapaian kualitas skripsi sebagai sebuah karya penelitian. Penelitian ini adalah penelitian evaluasi deskriptif. Penelitian dilakukan pada Jurusan PAI FITK IAIN Surakarta. Hasil penelitian menunjukkan beberapa hal. Pertama, sebagian besar skripsi mahasiswa PAI tabun 2012 menggunakan metode penelitian kualitatif. Kedua, kualitas skripsi mahasiswa PAI tabun 2012 secara umum sedang baik pada skripsi yang menggunakan metode penelitian kuantitatif maupun kualitatif. Ketiga, skripsi yang menggunakan metode penelitian kuantitatif memiliki indeks kualitas yang lebih tinggi dibandingkan skripsi yang menggunakan metode penelitian kualitatif. Keempat, pada skripsi yang menggunakan metode penelitian kuantitatif, kualitas rendah terdapat pada unsur latar belakang masalab dan kerangka berpikir. Kelima, pada skripsi yang menggunakan metode penelitian kualitatif, kualitas rendah terdapat pada unsur judul penelitian dan latar belakang masalah.
\end{abstract}

Kata Kunci: Evaluasi, Kualitas, Skripsi

Permalink/DOI: http://dx.doi.org/10.18326/infsl3.v9i2.417-444 


\section{Pendahuluan}

Skripsi adalah salah satu bentuk kewajiban akademik yang harus ditunaikan oleh mahasiswa yang menyelesaikan pendidikan pada jenjang sarjana (S1). Mata kuliah ini diadakan untuk melatih kemampuan mahasiswa dalam membuat pemecahan masalah dalam bidang pendidikannya secara ilmiah. Di samping itu, mata kuliah ini juga melatih mahasiswa menuangkan gagasan secara tertulis dan menyusun argumentasi secara sistematis.

Keberadaan mata kuliah skripsi tidak dapat dilepaskan dari usaha penjaminan kualitas lembaga pendidikan secara keseluruhan. Kualitas skripsi mahasiswa merupakan bagian dari kualitas lembaga. Usaha mendorong kualitas lembaga harus disertai usaha mendorong kualitas skripsi yang merupakan produk akhir mahasiswa sebelum lulus.

Secara internal pengendalian kualitas skripsi dilakukan di bawah pengendalian pembimbing yang ditunjuk. Pengendalian kualitas juga dilakukan oleh para penguji pada saat seminar proposal dan ujian skripsi (munaqosab). Ujian skripsi merupakan eksaminasi akhir untuk mengendalikan kualitas skripsi secara internal.

Kualitas berhubungan dengan derajad keseragaman (degree of agreement) produk atau jasa. Derajad keseragaman mencerminkan kepastian tentang standar layanan. Layanan yang standar menjadikan sebuah lembaga menghasilkan produk atau jasa yang standar yang dapat diramalkan oleh para pelanggan.

Perbedaan persepsi pembimbing dan penguji dalam memberikan pengertian tentang kualitas skripsi menjadikan kualitas skripsi menjadi acak dan tidak dapat diramalkan. Jika pengertian kualitas skripsi diserahkan kepada persepsi subjektif pembimbing dan penguji menurut pengalaman individual mereka, maka skripsi menjadi produk yang tidak dapat distandarisasikan.

Buku panduan dibuat untuk mencegah terlampau lebarnya varians standar kulitas skripsi. Tetapi karena buku panduan seringkali hanya membakukan soal administrasi, teknik penulisan, dan halhal teknis lainnya, maka panduan sering tidak berhasil mencegah keragaman kualitas skripsi yang dihasilkan para mahasiswa. Pada 
keadaan demikian, evaluasi kualitas skripsi secara kelembagaan di tingkat Jurusan, fakultas dan IAIN menjadi kebutuhan.

Evaluasi kualitas skripsi secara kelembagaan belum pernah dilakukan di Jurusan PAI, FITK maupun IAIN Surakarta. Padahal evaluasi kualitas itu diperlukan untuk memberikan kepastian standar pelayanan, sehingga jurusan, fakultas dan institut menjadi lembaga yang dapat diramalkan perilakunya. Penelitian ini diharapkan menjadi jalan merintis upaya memulai melaksanakan evaluasi kualitas skripsi secara kelembagaan. Berdasarkan latar belakang masalah tersebut, penelitian ini merumuskan masalah : 1) Bagaimana kualitas skripsi di Jurusan PAI FITK IAIN Surakarta? 2) Sejauh mana kualitas skripsi telah dicapai di Jurusan PAI FITK IAIN Surakarta?

\section{Pengertian Evaluasi}

Evaluasi berasal dari kata dalam bahasa Inggris evaluation yang berarti penilaian. Menurut Echols dan Shadily (2003: 219), mengevaluasi (to evaluate) mempunyai arti "menilai" atau "menaksir". Oleh karenanya beberapa pendapat menyatakan bahwa evaluasi merupakan kegiatan menentukan nilai. Winkel (1996: 475) menjelaskan evaluasi sebagai penentuan sampai berapa jauh sesuatu berharga, bermutu dan bernilai.

Beberapa pendapat lain menyatakan evaluasi sebagai pengambilan keputusan yang dibuat berdasarkan hasil pengukuran dan kriteria. Pendapat ini didasari oleh pemahaman bahwa pengumpulan data melalui pengukuran merupakan bagian terpenting dalam evaluasi. Ketepatan keputusan evaluasi sangat tergantung pada ketepatan dan kecermatan pengukuran. Menurut Arikunto (1995 : 3), evaluasi berarti mengambil keputusan terhadap hasil pengukuran. Pengukuran (measurement) adalah proses membandingkan sesuatu dengan ukurannya. Weis (1984: 12) menyatakan bahwa evaluasi dilakukan dengan menterjemahkan bukti menjadi pengertian kuantitatif dan membandingkan hasil tersebut dengan kriteria yang telah ditetapkan. Azwar (2001: 7) menarik kesimpulan bahwa evaluasi mempunyai tiga karakteristik yaitu: (1) perbandingan antara hasil ukur dengan suatu norma atau 
kriteria, (2) hasilnya bersifat kualitatif, dan (3) hasilnya dinyatakan secara evaluatif.

\section{Kualitas}

Kualitas atau mutu berhubungan dengan kemampuan produk atau jasa untuk memberikan kepuasan kepada pelanggan. Pelanggan memperoleh kepuasan apabila penampilan produk atau jasa melampaui ekspektasi pelanggan. Oleh karenanya, produk atau jasa dikatakan berkualitas jika penampilannya melampaui ekspektasi pelanggan. Jika penampilan produk atau jasa melampaui ekspektasi pelanggan, maka pelanggan merasakan bahwa dirinya telah memperoleh produk atau jasa yang berkualitas dan karenanya memperoleh kepuasan. Menurut Buddy Ibrahim (2000), apabila konsumen yang membeli atau memakai suatu barang atau jasa yang memenuhi atau bahkan melampaui harapan konsumen, bukan saja satu kali tapi berulang kali sehingga memberikan kepuasan, maka persepsi konsumen adalah dia telah mendapatkan produk atau jasa berkualitas.

Salah satu indikator mutu adalah konsistensi penampilan produk yang memberikan kepuasan kepada pelanggan. Kemampuan memberikan kepuasan bukan untuk satu kali, tetapi berulang kali dalam jangka panjang, sehingga terbangun persepsi bahwa pelanggan memperoleh produk atau jasa berkualitas. Menurut Richard F Gerson (2004), mutu dan pelayanan adalah sarana untuk mencapai kepuasan dan ikatan. Parasuraman et al (Bambang Suryadi, 2006), salah satu determinan mutu adalah keajegan (reliability). Hal yang sama diungkapkan oleh Paine, Turner dan Pryke (1992). Menurut mereka mutu adalah derajad keseragaman produk yang dapat diramalkan. Untuk mencapai derajad keseragaman itu, Crosby (Sallis, 2008 : 111), menyarankan untuk membuat produk atau jasa yang tanpa cacat (zero defects).

\section{Skripsi}

Skripsi adalah sebuah karya ilmiah berbentuk penelitian yang dilakukan oleh mahasiswa sebagai persyaratan untuk menyelesaikan studi pada pendidikan jenjang sarjana (S1). Sebagai karya ilmiah 
berbentuk penelitian maka skipsi mengikuti kaidah-kaidah dalam penelitian.

Penelitian (re-search) adalah upaya pemecahan masalah yang dilakukan secara ilmiah. Pemecahan masalah secara ilmiah dimaksudkan bahwa setiap langkah dilakukan secara sistematis hingga dicapai hasil penelitian.

Secara tipikal, penelitian dapat menggunakan metode penelitian kuantitatif dan kualitatif. Walaupun metodologi penelitian terus mengalami perkembangan, namun semuanya dapat dikategorikan ke dalam dua arus utama tersebut.

Penelitian kuantitatif berbeda dengan penelitian kualitatif karena keduanya memiliki landasan epistimologis yang berbeda. Keduanya sekurangnya dapat dibedakan dalam dua hal. Pertama, penelitian kuantitatif berhubungan dengan hasil atau produk, sedang penelitian kualitatif berhubungan dengan proses atau dinamika. Kedua, penelitian kuantitatif bertujuan untuk menemukan hukum umum, sedang penelitian kualitatif bertujuan untuk memahami keunikan.

Perbedaan kedua metode, selanjutnya juga berpengaruh terhadap perbedaan ukuran untuk melihat kualitasnya. Kualitas penelitian kuantitatif dapat dilihat dari segi : latar belakang masalah, identifikasi masalah, pembatasan masalah, perumusan masalah, teori, kerangka berpikir, hipotesis, metode penelitian, populasi dan sampel, teknik pengumpulan data, penulisan butir instrumen, teknik analisis data, hasil penelitian dan penutup (Purwanto, 2010). Adapun kualitas penelitian kualitatif dapat dilihat dari segi : latar belakang masalah, perumusan masalah, teori, pendekatan penelitian, subjek dan informan penelitian, metode pengumpulan data, pemeriksaan keabsahan data, teknik analisis data, hasil penelitian dan penutup (Purwanto, 2011).

Penelitian tentang evaluasi kualitas skripsi pernah dilakukan oleh Rini Susanti untuk tesis magisternya di Universitas Negeri Jakarta tahun 1997 (Susanti, 1997). Penelitian dilakukan atas skripsi mahasiswa Pendidikan Sejarah Universitas Lampung menggunakan metode penelitian evaluasi. Hasil penelitiannya menyimpulkan 
bahwa rata-rata kualitas skripsi di Pendidikan Sejarah Universitas Lampung masih tergolong rendah.

Penelitian tentang evaluasi penelitian juga dilakukan oleh Pilipus M Kopeuw di Perguruan Tinggi Teologi (Kopeuw, 2012). Hasil penelitiannya menunjukkan banyaknya terjadi kekacauan dalam metodologi penelitian, misalnya skripsi menggunakan metode penelitian kuantitiatif, tetapi analisis datanya menggunakan analisis data penelitian kualitatif. Dia juga menyimpulkan adanya keterbatasan pengetahuan dosen pembimbing tentang metodologi penelitian yang menyebabkan kualitas skripsi mahasiswa rendah.

\section{Metode penelitian}

Penelitian ini merupakan penelitian evaluasi deskriptif. Dilihat dari segi tujuannya penelitian ini merupakan penelitian evaluasi karena bertujuan untuk mengevaluasi kualitas skripsi. Dari segi masalahnya, penelitian ini merupakan penelitian deskriptif karena mempersoalkan satu variabel, yaitu kualitas skripsi. Penelitian dilakukan pada Jurusan PAI FITK IAIN Surakarta. Penelitian dilakukan dalam 3 bulan yaitu pada bulan Agustus sampai Oktober tahun 2013.

Populasi penelitian ini adalah seluruh skripsi Jurusan PAI FITK yang dikeluarkan pada tahun 2012 sebanyak 166 buah skripsi. Sampel penelitian ini adalah skripsi Jurusan PAI FITK yang dikeluarkan pada tahun 2012 yang tersedia di perpustakaan FITK sebanyak 50 buah skripsi. Jumlah tersebut terbagi ke dalam empat kelompok metode penelitian yang digunakan yang ditabulasikan sebagai berikut: 
Tabel 1.

Metode penelitian yang digunakan pada sampel penelitian

\begin{tabular}{lll}
\hline No & \multicolumn{1}{c}{ Metode penelitian } & Jumlah \\
\hline 1 & Kuantitatif & 5 \\
2 & Kualitatif & 29 \\
3 & PTK & 6 \\
4 & Literatur & 10 \\
& Jumlah & 50 \\
\hline
\end{tabular}

Dari data tersebut terlihat bahwa sebagian besar minat penelitian mahasiswa adalah menggunakan metode penelitian kualitatif sebanyak 29 orang, diikuti oleh metode penelitian literatur sebanyak 10 orang dan metode penelitian tindakan kelas sebanyak 6 orang. Minat terendah mahasiswa adalah melakukan penelitian menggunakan metode penelitian kualitatif sebanyak 5 orang.

Teknik sampling yang digunakan adalah sampling purposif karena dua pertimbangan yaitu (1) ketersediaannya di arsip perpustakaan fakultas, dan (2) metode penelitian yang digunakan adalah metode penelitian kuantitatif dan kualitatif. Pemilihan fokus evaluasi hanya atas penelitian yang menggunakan metode penelitian kuantitatif dan kualitatif karena arus utama (mainstream) dalam penelitian adalah kuantitatif dan kualitatif. Metode-metode lain merupakan varian dan pengembangan dari kedua arus utama ini.

Pengumpulan data dilakukan menggunakan lembar penilaian menggunakan skala penilaian (rating scale) dengan skala $1-5$, di mana skor-skor merupakan ukuran kualitas: 1 = sangat kurang, 2 = kurang, 3 = cukup, 4 = baik, $5=$ sangat baik. Kisi-kisi lembar penilaian skripsi yang menggunakan metode penelitian kuantitatif adalah sebagai berikut: 
Tabel 2.

Kisi-kisi lembar penilaian skripsi yang menggunakan metode penelitian kuantitatif

\begin{tabular}{|c|c|c|c|}
\hline No & Indikator kualitas & Nomor butir & Jumlah \\
\hline 1 & Judul penelitian & 1 & 1 \\
\hline 2 & Latar belakang masalah & 2,3 & 2 \\
\hline 3 & Identifikasi masalah & 4,5 & 2 \\
\hline 4 & Pembatasan masalah & 6,7 & 2 \\
\hline 5 & Perumusan masalah & 8,9 & 2 \\
\hline 6 & Teori & 10,11 & 2 \\
\hline 7 & Kerangka berpikir & 12,13 & 2 \\
\hline 8 & Hipotesis & 14,15 & 2 \\
\hline 9 & Metode penelitian & 16,17 & 2 \\
\hline 10 & Teknik sampling & $18,19,20$ & 3 \\
\hline 11 & $\begin{array}{l}\text { Teknik pengumpulan } \\
\text { data }\end{array}$ & $\begin{array}{l}21,22,23,24,25,26 \\
27,28\end{array}$ & 8 \\
\hline 12 & $\begin{array}{l}\text { Penulisan } \quad \text { butir } \\
\text { instrumen }\end{array}$ & $29,30,31$ & 3 \\
\hline 13 & Teknik analisis data & $32,33,34,35$ & 4 \\
\hline 14 & $\begin{array}{l}\text { Penyajian } \quad \text { hasil } \\
\text { penelitian }\end{array}$ & $36,37,38$ & 3 \\
\hline \multirow[t]{2}{*}{15} & Kesimpulan dan saran & 39,40 & 2 \\
\hline & JUMLAH & & 40 \\
\hline
\end{tabular}


Adapun kisi-kisi lembar penilaian skripsi yang menggunakan metode penelitian kualitatif adalah sebagai berikut:

Tabel 3.

Kisi-kisi lembar penilaian skripsi yang menggunakan metode penelitian kualitatif

\begin{tabular}{cllc}
\hline No & \multicolumn{1}{c}{ Indikator kualitas } & \multicolumn{1}{c}{ Nomor butir } & Jumlah \\
\hline 1 & Judul penelitian & 1 & 1 \\
2 & Latar belakang masalah & $2,3,4$ & 3 \\
3 & Perumusan masalah & 5,6 & 2 \\
4 & Teori & 7,8 & 2 \\
5 & Pendekatan penelitian & 9,10 & 2 \\
6 & $\begin{array}{l}\text { Subjek dan informan } \\
\text { penelitian }\end{array}$ & 11,12 & 2 \\
7 & $\begin{array}{l}\text { Metode pengumpulan } \\
\text { data }\end{array}$ & $13,14,15,16,17,18,19$, & 9 \\
8 & $\begin{array}{l}\text { Pemeriksaan keabsahan } \\
\text { data }\end{array}$ & 22,23 & 2 \\
9 & Teknik analisis data & 24,25 & 2 \\
10 & Penyajian hasil penelitian & $26,27,28$ & 3 \\
11 & Kesimpulan dan saran & 29,30 & 2 \\
& JumLAH
\end{tabular}

Kedua lembar penilaian skripsi telah diuji validitas dan reliabilitasnya. Lembar penilaian tersebut diuji validitasnya dengan cara melakukan telaah butir (item review). Hasil penelaahan butir menunjukkan semua butir valid karena butir yang ditulis bersesuaian dengan kisi-kisinya. Pengujian reliabilitas lembar penilaian dilakukan 
menggunakan uji Alpha Cronbach. Hasil uji dibandingkan dengan $r$ tabel pada taraf kesalahan 5\%. Hasil perhitungan koefisien reliabilitas menggunakan SPSS versi 13.00 disajikan pada lampiran 4. Berdasarkan hasil perhitungan tersebut dapat diringkaskan hasil pengujian reliabilitas sebagai berikut :

\section{Tabel 4. \\ Ringkasan Hasil Uji Relibilitas \\ Lembar Penilaian Kualitas Skripsi}

\begin{tabular}{lllll}
\hline No & $\begin{array}{c}\text { Lembar penilaian } \\
\text { kualitas skripsi }\end{array}$ & $\begin{array}{c}\text { Koefisien } \mathrm{r} \\
\text { hitung }\end{array}$ & $\begin{array}{c}\text { Koefisien } \mathrm{r} \\
\text { tabel }\end{array}$ & Keputusan \\
\hline 1 & $\begin{array}{l}\text { Penelitian } \\
\text { kuantitatif }\end{array}$ & 0,948 & 0,669 & Reliabel \\
2 & Penelitian kualitatif & 0,848 & 0,301 & Reliabel \\
\hline
\end{tabular}

Analisis data dilakukan menggunakan rata-rata untuk menghitung indeks kualitas skripsi dan menggunakan persentase untuk melihat tingkat ketercapaian kualitas penelitian. Langkahlangkah dalam melakukan analisis data adalah sebagai berikut : 1) menentukan kriteria kualitas menggunakan acuan norma, 2) menghitung indeks kualitas skripsi, 3) membandingkan indeks kualitas skripsi dengan kriterianya, 4) membuat keputusan tentang kualitas skripsi, dan 5) menghitung tingkat ketercapaian kualitas skripsi.

\section{Hasil Penelitian}

Data kualitas skripsi mahasiswa PAI tahun 2012 disajikan dalam bentuk tabel dan grafik sebagai berikut :

1. Kualitas skripsi mahasiswa PAI tahun 2012 secara keseluruhan

Kualitas skripsi secara keseluruhan disajikan menggunakan ukuran berbentuk indeks. Indeks kualitas skripsi dihitung dengan membagi skor total kualitas sebuah skripsi dengan banyak butir penilaiannya. Indeks kualitas skripsi secara keseluruhan dapat disajikan dalam tabel berikut: 


\section{Tabel 5.}

Indeks kualitas skripsi mahasiswa PAI Tahun 2012

\begin{tabular}{cccc}
\hline Indeks & Kategori & Frekuensi & Persen \\
\hline $2,00-2,99$ & Rendah & 3 & 12,5 \\
$3,00-3,99$ & Sedang & 28 & 75 \\
$4,00-5,00$ & Tinggi & 3 & 12,5 \\
Jumlah & & 34 & \\
\hline
\end{tabular}

Dari tabel terlihat dari 34 skripsi yang diteliti, sebagian besar memiliki kualitas dalam rentangan sedang yaitu 75\%. Sebanyak $12,5 \%$ memiliki kualitas rendah dan 12,5\% memiliki kualitas tinggi. Hal itu dapat disajikan dalam bentuk grafik sebagai berikut:

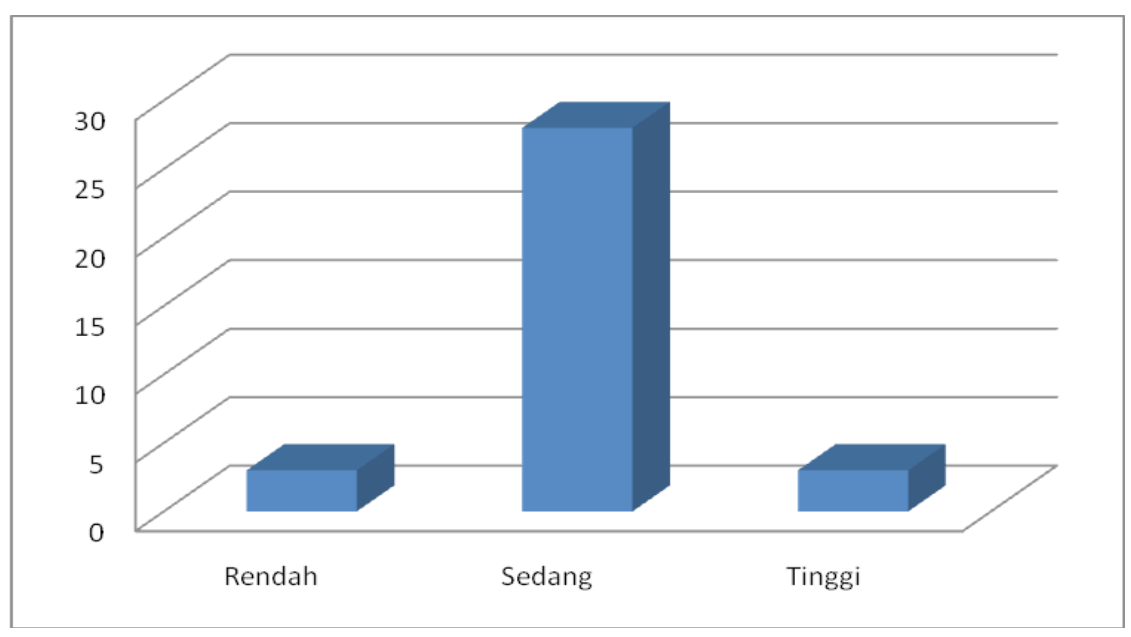

\section{Gambar 1.}

\section{Indeks Kualitas Skripsi Mahasiswa PAI Tahun 2012}

2. Kualitas skripsi mahasiswa PAI tahun 2012 yang menggunakan metode penelitian kuantitatif

Data kualitas skripsi mahasiswa PAI tahun 2012 yang menggunakan metode penelitian kuantitatif dapat disajikan dalam bentuk tabel sebagai berikut : 
Tabel 6.

Kualitas skripsi mahasiswa PAI tahun 2012 yang menggunakan metode penelitian kuantitatif

\begin{tabular}{cccc}
\hline Indeks & Kategori & Frekuensi & Persen \\
\hline $2,00-2,99$ & Rendah & 0 & 0 \\
$3,00-3,99$ & Sedang & 2 & 40 \\
$4,00-5,00$ & Tinggi & 3 & 60 \\
Jumlah & & 5 & \\
\hline
\end{tabular}

Dari tabel terlihat bahwa dari 5 skripsi yang menggunakan metode penelitian kuantitatif yang diteliti, tidak terdapat skripsi yang kualitasnya rendah (0\%). Sebanyak 40\% skripsi memiliki kualitas sedang, dan sebanyak 60\% skripsi memiliki kualitas tinggi. Data tersebut dapat disajikan dalam bentuk grafik sebagai berikut:

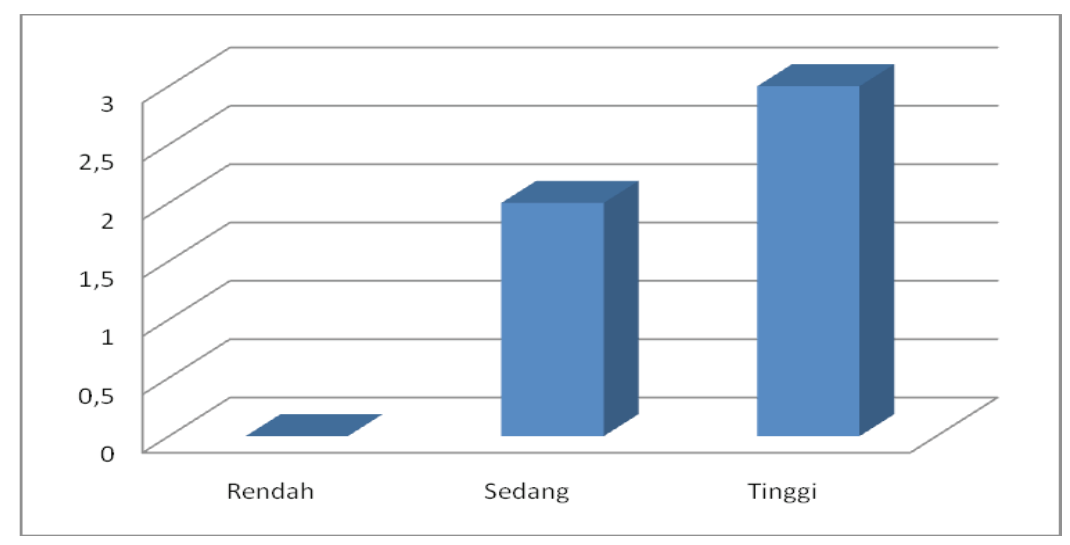

Gambar 2.

\section{Kualitas skripsi mahasiswa PAI tahun 2012 yang menggunakan metode penelitian kuantitatif}

3. Kualitas skripsi mahasiswa PAI tahun 2012 yang menggunakan metode penelitian kualitatif

Kualitas skripsi mahasiswa PAI tahun 2012 yang menggunakan metode penelitian kualitatif dapat disajikan dalam bentuk tabel sebagai berikut : 
Tabel 7.

Kualitas Skripsi Mahasiswa PAI Tahun 2012 Yang Menggunakan Metode Penelitian Kualitatif

\begin{tabular}{cccc}
\hline Indeks & Kategori & Frekuensi & Persen \\
\hline $2,00-2,99$ & Rendah & 3 & 10 \\
$3,00-3,99$ & Sedang & 26 & 90 \\
$4,00-5,00$ & Tinggi & 0 & 0 \\
Jumlah & & 29 & \\
\hline
\end{tabular}

Dari tabel dapat diketahui bahwa dari 26 buah skripsi menggunakan metode penelitian kualitatif yang diteliti, terdapat 3 buah (10\%) memiliki kualitas rendah, 26 buah (90\%) memiliki kualitas sedang, dan tidak ada yang memiliki kualitas tinggi (0\%). Data kualitas skripsi mahasiswa PAI tahun 2012 yang menggunakan metode penelitian kualitatif dapat disajikan dalam bentuk grafik sebagai berikut :



Gambar 3.

Kualitas skripsi mahasiswa PAI tahun 2012 yang menggunakan metode penelitian kualitatif 
4. Perbandingan kualitas skripsi mahasiswa PAI tahun 2012 antara yang menggunakan metode penelitian kuantitatif dengan kualitatif

Kualitas skripsi mahasiswa PAI tahun 2012 dapat dibandingkan antara yang menggunakan metode penelitian kuantitatif dengan kualitatif dalam ukuran persentase karena jumlah skripsi yang diteliti tidak sama jumlahnya. Perbandingan keduanya dapat disajikan dalam bentuk tabel sebagai berikut :

Tabel 8.

Perbandingan kualitas skripsi mahasiswa PAI tahun 2012 antara yang menggunakan metode penelitian kuantitatif dengan kualitatif

(dalam \% dan indeks)

\begin{tabular}{ccc}
\hline \multirow{2}{*}{ Kualitas } & \multicolumn{2}{c}{ Metode penelitian } \\
& Kuantitatif & Kualitatif \\
\hline Rendah & 0 & 10 \\
Sedang & 40 & 90 \\
Tinggi & 60 & 0 \\
Indeks & 3,92 & 3,47 \\
\hline
\end{tabular}

Dari tabel diketahui bahwa skripsi mahasiswa PAI tahun 2012 yang menggunakan metode penelitian kuantitatif memiliki kualitas yang lebih tinggi dibandingkan yang menggunakan metode penelitian kualitatif. Sebanyak 60\% skripsi yang menggunakan metode penelitian kuantitatif memiliki kualitas tinggi dan tidak ada (0\%) skrpsi yang menggunakan metode penelitian kuantitatif memiliki kualitas rendah. Sebaliknya, tidak ada (0\%) skripsi yang menggunakan metode penelitian kualitatif memiliki kualitas tinggi, dan sebanyak 10\% skripsi yang menggunakan metode penelitian 
kualitatif memiliki kualitas rendah. Perbandingan kualitas skripsi mahasiswa PAI tahun 2012 antara yang menggunakan metode penelitian kuantitatif dengan kualitatif dapat disajikan dalam bentuk grafik sebagai berikut :

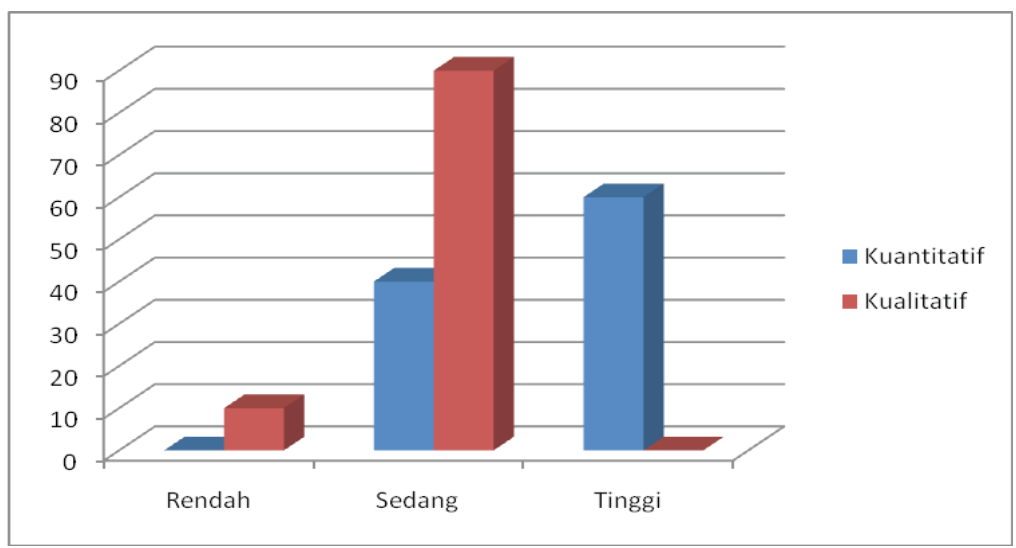

Gambar 4.

Perbandingan Kualitas Skripsi Mahasiswa PAI Tahun 2012 Antara Yang Menggunakan Metode Penelitian Kuantitatif Dengan Kualitatif

Lebih rendahnya kualitas skripsi yang menggunakan metode penelitian kualitatif dibandingkan skripsi yang menggunakan metode penelitian kuantitatif disebabkan oleh kurang jelasnya pelaksanaan kegiatan pengumpulan data, pemeriksaan keabsahan data dan analisis data. Indeks kualitas pelaksanaan ketiganya dalam skripsi yang menggunakan metode penelitian kuantitatif dan kualitatif dapat dibandingkan sebagai berikut: 
Tabel 9.

Indeks Kualitas Pelaksanaan Pengumpulan Data, Pemeriksaan Keabsahan Data Dan Analisis Data Pada Skripsi Yang Menggunakan Metode Penelitian Kuantitatif Dan Kualitatif

\begin{tabular}{cccc}
\hline No & Pelaksanaan & Kuantitatif & Kualitatif \\
\hline 1 & Uji coba instrumen & 4,9 & - \\
2 & Pengumpulan data & 4,15 & 3,31 \\
3 & Pemeriksaan keabsahan data & - & 2,0 \\
4 & Analisis data & 3,4 & 2,0 \\
\hline
\end{tabular}

\section{Analisis}

Analisis data dilakukan dengan cara menghitung indeks kualitas skripsi dan selanjutnya membuat keputusan dengan cara membandingkan indeks tersebut dengan kriterianya. Hal itu dilakukan atas kualitas skripsi secara keseluruhan maupun per komponen. Dari analisis juga diketahui prosentase tingkat pencapaian kualitas skripsi baik secara keseluruhan maupun untuk tiap-tiap unsur. Adapun kriteria yang digunakan sebagai dasar untuk memberikan penilaian terhadap kualitas skripsi adalah sebagai berikut:

Tabel 10.

Kriteria penilaian kualitas skripsi

\begin{tabular}{ccc}
\hline No & Indeks & Kualitas \\
\hline 1 & $2,00-2,99$ & Rendah \\
2 & $3,00-3,99$ & Sedang \\
3 & $4,00-5,00$ & Tinggi \\
\hline
\end{tabular}

Penilaian dipisahkan antara penilaian atas skripsi yang menggunakan metode penelitian kuantitatif dan kualitatif karena keduanya memiliki unsur yang berbeda. 
1. Menghitung indeks kualitas skripsi yang menggunakan metode penelitian kuantitatif

a. Kualitas skripsi secara keseluruhan

$$
\text { Indeks }=\frac{783}{40 \times 5}=3,92
$$

b. Kualitas judul penelitian

$$
\text { Indeks }=\frac{25}{5}=5
$$

c. Kualitas latar belakang masalah

$$
\text { Indeks }=\frac{28}{5 \times 2}=2,8
$$

d. Kualitas identifikasi masalah

$$
\text { Indeks }=\frac{31}{2 \times 5}=3,1
$$

e. Kualitas pembatasan masalah

$$
\text { Indeks }=\frac{41}{2 \times 5}=4,1
$$

f. Kualitas perumusan masalah

$$
\text { Indeks }=\frac{50}{2 \times 5}=5
$$

g. Kualitas teori

$$
\text { Indeks }=\frac{34}{2 \times 5}=3,4
$$

h. Kualitas kerangka berpikir

$$
\text { Indeks }=\frac{27}{2 \times 5}=2,7
$$

i. Kualitas hipotesis

$$
\text { Indeks }=\frac{34}{2 \times 5}=3,4
$$


j. Kualitas metode penelitian

Indeks $=\frac{50}{2 \times 5}=5$

k. Kualitas teknik sampling

Indeks $=\frac{70}{3 \times 5}=4,67$

1. Kualitas teknik pengumpulan data

Indeks $=\frac{181}{5 \times 8}=4,53$

m. Kualitas penulisan butir instrumen

Indeks $=\frac{49}{3 \times 5}=3,27$

n. Kualitas teknik analisis data

$$
\text { Indeks }=\frac{68}{4 \times 5}=3,4
$$

o. Kualitas penyajian hasil penelitian

$$
\text { Indeks }=\frac{55}{3 \times 5}=3,67
$$

p. Kualitas kesimpulan dan saran

$$
\text { Indeks }=\frac{40}{2 \times 5}=4
$$

2. Menghitung indeks kualitas skripsi yang menggunakan metode penelitian kualitatif

a. Kualitas skripsi secara keseluruhan

$$
\text { Indeks }=\frac{3019}{29 \times 30}=3,47
$$

b. Kualitas judul penelitian

$$
\text { Indeks }=\frac{76}{29}=2,62
$$

c. Kualitas latar belakang masalah 


$$
\text { Indeks }=\frac{210}{29 \times 3}=2,41
$$

d. Kualitas perumusan masalah

$$
\text { Indeks }=\frac{210}{29 \times 3}=2,41
$$

e. Teori

$$
\text { Indeks }=\frac{249}{2 \times 29}=4,29
$$

f. Pendekatan penelitian

$$
\text { Indeks }=\frac{214}{2 \times 29}=3,69
$$

g. Subjek dan informan penelitian

$$
\text { Indeks }=\frac{225}{2 \times 29}=3,88
$$

h. Metode pengumpulan data

$$
\text { Indeks }=\frac{865}{29 \times 9}=3,31
$$

i. Pemeriksaan keabsahan data

$$
\text { Indeks }=\frac{191}{2 \times 29}=3,29
$$

j. Teknik analisis data

$$
\text { Indeks }=\frac{203}{2 \times 29}=3,5
$$

k. Penyajian hasil penelitian

$$
\text { Indeks }=\frac{336}{3 \times 29}=3,86
$$

1. Kesimpulan dan saran

$$
\text { Indeks }=\frac{236}{2 \times 9}=4,07
$$


3. Keputusan penilaian kualitas skripsi yang menggunakan metode penelitian kuantitatif

Berdasarkan perhitungan indeks kualitas skripsi dan membandingkannya dengan kriteria kualitas dapat diambil keputusan yang ditabulasikan sebagai berikut:

Tabel 11.

Keputusan penilaian kualitas skripsi yang menggunakan metode penelitian kuantitatif

\begin{tabular}{|c|c|c|c|c|}
\hline No & Unsur & Indeks & Kategori & $\begin{array}{c}\text { Pencapaian } \\
(\%)\end{array}$ \\
\hline 1 & Kualitas keseluruhan & 3,92 & Sedang & 78,4 \\
\hline 2 & Judul penelitian & 5 & Tinggi & 100 \\
\hline 3 & Latar belakang masalah & 2,8 & Rendah & 56 \\
\hline 4 & Identifikasi masalah & 3,1 & Sedang & 62 \\
\hline 5 & Pembatasan masalah & 4,1 & Tinggi & 82 \\
\hline 6 & Perumusan masalah & 5 & Tinggi & 100 \\
\hline 7 & Teori & 3,4 & Sedang & 68 \\
\hline 8 & Kerangka berpikir & 2,7 & Rendah & 54 \\
\hline 9 & Hipotesis & 3,4 & Sedang & 68 \\
\hline 10 & Metode penelitian & 5 & Tinggi & 100 \\
\hline 11 & Teknik sampling & 4,67 & Tinggi & 93,4 \\
\hline 12 & Teknik pengumpulan data & 4,53 & Tinggi & 90,6 \\
\hline 13 & Penulisan butir instrumen & 3,27 & Sedang & 65,4 \\
\hline 14 & Teknik analisis data & 3,4 & Sedang & 68 \\
\hline
\end{tabular}


15 Penyajian hasil penelitian

$$
3,67
$$

Sedang

73,4

16 Kesimpulan dan saran

4

Tinggi

80

4. Keputusan penilaian kualitas skripsi yang menggunakan metode penelitian kualitatif

Berdasarkan perhitungan indeks kualitas skripsi dan membandingkannya dengan kriteria kualitas dapat diambil keputusan yang ditabulasikan sebagai berikut :

\section{Tabel 12.}

Keputusan penilaian kualitas skripsi yang menggunakan metode penelitian kualitatif

\begin{tabular}{ccccc}
\hline No & Unsur & Indeks & Kategori & $\begin{array}{c}\text { Pencapaian } \\
(\%)\end{array}$ \\
\hline 1 & Kualitas keseluruhan & 3,47 & Sedang & 69,4 \\
2 & Judul penelitian & 2,62 & Rendah & 52,4 \\
3 & Latar belakang masalah & 2,41 & Rendah & 48,2 \\
4 & Perumusan masalah & 3,69 & Sedang & 73,8 \\
5 & Teori & 4,29 & Tinggi & 85,8 \\
6 & Pendekatan penelitian & 3,69 & Sedang & 73,8 \\
7 & Subjek dan informan & 3,88 & Sedang & 77,6 \\
8 & Metode pengumpulan data & 3,31 & Sedang & 66,2 \\
9 & Pemeriksaan keabsahan & 3,29 & Sedang & 65,8 \\
10 & Teknik analisis data & 3,5 & Sedang & 70 \\
11 & Penyajian hasil penelitian & 3,86 & Sedang & 77,2 \\
12 & Kesimpulan dan saran & 4,07 & Tinggi & 81,4 \\
\hline
\end{tabular}


Sebaran metode penelitian yang digunakan dalam skripsi mahasiswa

Sebagian besar minat penelitian mahasiswa adalah menggunakan metode penelitian kualitatif sebanyak 29 orang, diikuti oleh metode penelitian literatur sebanyak 10 orang dan metode penelitian tindakan kelas sebanyak 6 orang. Minat terendah mahasiswa adalah melakukan penelitian menggunakan metode penelitian kualitatif sebanyak 5 orang. Kecenderungan sebagian besar skripsi menggunakan metode penelitian kualitatif beberapa hal. Pertama, kecenderungan kualifikasi dosen yang sebagian besar memiliki latar belakang penguasaan metode penelitian kualitatif. Kecenderungan ini membuat kebanyakan pembimbing mengarahkan mahasiswa yang mengambil skripsi untuk menggunakan metode penelitian kualitatif. Kedua, ketidakpahaman mahasiswa bahwa metode penelitian kualitatif membutuhkan persyaratan kemampuan yang lebih sedikit dibandingkan dengan metode penelitian kuantitatif. Metode ini dipahami sebagai tidak menuntut kemampuan teknis yang rumit sebagaimana dituntut penelitian kualitatif. Ketiga, kebijakan makro baik di tingkat institut, fakultas maupun jurusan yang menempatkan metode penelitian kualitatif dinilai memiliki bobot lebih dibandingkan dengan penelitian kuantitatif. Oleh karenanya dalam banyak kesempatan mereka mendorong mahasiswa untuk memilih menggunakan metode penelitian kualitatif.

\section{Kualitas skripsi mahasiswa Jurusan PAI FITK IAIN Surakarta}

Secara umum kualitas skripsi mahasiswa Jurusan PAI FITK IAIN Surakarta dalam kategori sedang. Hal itu berlaku baik pada kualitas skripsi secara keseluruhan, kualitas skripsi yang menggunakan metode penelitian kuantitatif, maupun kualitas skripsi yang menggunakan metode penelitian kualitatif. Kemampuan melakukan penyelidikan dan menuangkan gagasan secara tertulis masih menjadi persoalan umum mahasiswa, bukan hanya mahasiswa IAIN Surakarta. Padahal kedua keterampilan itu merupakan dasar bagi kemampuan mahasiswa untuk memiliki kepekaan terhadap masalah dan menuliskan laporan hasil penelitian. Kemampuan itu memang tidak dicapai instan. 
Kemampuan itu dicapai dengan usaha sungguh-sungguh dalam proses yang panjang, bahkan sebelum memasuki perguruan tinggi. Namun perguruan tinggi dapat melakukan akselerasi dengan membinanya melalui proses perkuliahan. Untuk mendukung kedua kompetensi tersebut perkuliahan perlu memberikan latihan sebanyak mungkin dalam membina kepekaan melihat masalah dan menuangkan gagasan secara tertulis.

Perbandingan kualitas skripsi antara skripsi yang menggunakan metode penelitian kuantitatif dengan yang menggunakan metode penelitian kualitatif.

Hasil penelitian menunjukkan bahwa kualitas skripsi yang menggunakan metode penelitian kuantitatif lebih baik dibandingkan skripsi yang menggunakan metode penelitian kualitatif. Sebaran data menunjukkan hal itu disebabkan karena dalam penelitian kualitatif banyak hal yang dilaporkan ternyata dalam kegiatannya tidak dilaksanakan. Misalnya, subjek penelitian ternyata tidak diamati aktivitasnya, informan penelitian ternyata tidak diwawancarai, pengumpulan data tidak jelas pelaksanaannya, teknik pemeriksaan keabsahan data yang dipilih tidak dilaksanakan, dan teknik analisis data yang dipilih juga banyak tidak dilaksanakan.

Lebih rendahnya kualitas skripsi yang menggunakan metode penelitian kualitatif dibandingkan dengan metode penelitian kualitatif berhubungan dengan ketidakpahaman mahasiswa yang memahami bahwa metode penelitian kualitatif tidak menuntut kemampuan teknis yang rumit sebagaimana dituntut oleh penelitian kualitatif. Padahal, dalam pelaksanaan pengumpulan data, pemeriksaan keabsahan data, dan analisis data, metode penelitian kualitatif menuntut kemampuan teknis yang tidak kalah rumit. Akibatnya, ketiga aspek ini menjadi sumber lebih rendahnya kualitas skripsi yang menggunakan metode penelitian kualitatif dibandingkan metode penelitian kualitatif. 
Kualitas skripsi yang menggunakan metode penelitian kuantitatif

Berdasarkan hasil analisis data diketahui bahwa kualitas skripsi mahasiswa PAI tahun 2012 yang menggunakan metode penelitian kuantitatif secara umum sedang dengan ditunjukkan dengan indeks kualitas 3,92 dan mencapai 78,4\% kualitas penelitian kuantitatif. Kualitas tinggi terdapat pada unsur judul penelitian, pembatasan masalah, perumusan masalah, metode penelitian, teknik sampling, dan teknik pengumpulan data, serta kesimpulan dan saran. Kualitas sedang dicapai oleh unsur identifikasi masalah, teori, hipotesis, penulisan butir instrumen, teknik analisis data, dan penyajian hasil penelitian. Hasil paling rendah dicapai dengan kualitas rendah pada unsur latar belakang masalah (mencapai 56\% kualitas penelitian) dan kerangka berpikir (mencapai 54\% kualitas penelitian).

Latar belakang masalah baru mencapai 56\% kualitas penelitian. Kebanyakan latar belakang masalah tidak menunjukkan adanya masalah, karena sesuatu yang diteliti tidak diletakkan dalam konteks yang problematik. Oleh karena sesuatu tidak didudukkan dalam konteks yang membuatnya terlihat sebagai sebuah masalah, maka tidak dirasakan adanya masalah dalam latar belakang masalah. Fakta-fakta empirik yang dapat menjadi konteks supaya hal yang diteliti tampak sebagai sebuah masalah tidak disampaikan. Akibatnya, seringkali proses lanjutannya yaitu identifikasi masalah menjadi lepas dari latar belakang masalah.

Rendahnya kualitas kerangka berpikir berhubungan dengan ketidakcukupan teori yang menjadi basis membangun logika berpikir yang dirumuskan dalam kerangka berpikir. Misalnya dalam penelitian "perbedaan prestasi belajar PAI antara siswa yang menempuh pendidikan diniyah dengan siswa yang tidak menempuh pendidikan diniyah", tidak mengkaji teori perbedaan tersebut. Teori itu akan menjadi bekal peneliti membangun logika berpikir. Kebanyakan kerangka berpikir memiliki rumusan yang kurang konklusif. Argumentasi yang dibangun tidak klimaks menuju konklusi yang jelas yang dibutuhkan oleh peneliti membuat dugaan hipotesis. 
Kualitas skripsi yang menggunakan metode penelitian kualitatif

Berdasarkan hasil analisis data diketahui bahwa kualitas skripsi mahasiswa PAI tahun 2012 yang menggunakan metode penelitian kualitatif secara umum sedang dengan ditunjukkan dengan indeks kualitas 3,47 dan mencapai 69,4\% kualitas penelitian kualitatif. Kualitas tinggi terdapat pada unsur teori serta kesimpulan dan saran. Kualitas sedang dicapai oleh unsur perumusan masalah, pendekatan penelitian, subjek dan informan penelitian, metode pengumpulan data, pemeriksaan keabsahan data, teknik analisis data dan penyajian hasil penelitian. Hasil paling rendah dicapai dengan kualitas rendah pada unsur judul penelitian dan latar belakang masalah.

Judul penelitian kualitatif baru mencapai kualitas sedang dengan mencapai 52,4\% kualitas penelitian. Kebanyakan judul penelitian kualitatif pada skripsi mahasiswa PAI tahun 2012 bersifat statis dan belum mencerminkan sebuah dinamika proses. Misalnya "peranan guru TK dalam meningkatkan kemampuan bersosialisasi di TK Bakti". Judul penelitian kualitatif yang mencerminkan sebuah dinamika akan menjadi "peningkatan kemampuan bersosialisasi pada siswa TK Bakti”. Contoh lain "pola pengawasan manajemen dana BOS". Supaya dinamis, judul itu dapat diubah menjadi "pelaksanaan pengawasan dana BOS".

Latar belakang masalah baru mencapai 48,\% kualitas penelitian. Kebanyakan latar belakang masalah tidak menjelaskan tentang kondisi seharusnya, kondisi senyatanya, dan kesenjangan antara keduanya yang menimbulkan situasi masalah. Ketiadaan ketiganya membuat banyak latar belakang masalah tidak memperlihatkan adanya masalah sehingga penelitian penting untuk dilakukan. 


\section{Kesimpulan}

Hasil penelitian menunjukkan; 1) Sebagian besar skripsi mahasiswa PAI tahun 2012 menggunakan metode penelitian kualitatif. Dominasi pilihan metode penelitian yang digunakan dalam skripsi berhubungan dengan kecenderungan kualifikasi kemampuan meneliti dosen, pemahaman bahwa metode penelitian kualitatif tidak menuntut kemampuan teknis yang rumit, dan motivasi kebijakan dari institusi. 2) Kualitas skripsi mahasiswa PAI tahun 2012 secara umum sedang baik pada skripsi yang menggunakan metode penelitian kuantitatif maupun kualitatif. Hal itu berhubungan dengan kemampuan mahasiswa melihat masalah dan menuangkan gagasan secara tertulis yang merupakan kompetensi dasar dalam melakukan penelitian. 3) Skripsi yang menggunakan metode penelitian kuantitatif memiliki indeks kualitas yang lebih tinggi dibandingkan skripsi yang menggunakan metode penelitian kualitatif. Hal itu berhubungan dengan kesalahpahaman mahasiswa bahwa metode penelitian kualitatif lebih mudah karena tidak menuntut kemampuan teknis yang rumit sebagaimana metode penelitian kualitatif. Padahal metode penelitian kualitatif juga memiliki kerumitan dalam hal melaporkan pengumpulan data, membuat catatan lapangan, melakukan pemeriksaan keabsahan data, dan melakukan analisis data. Akibatnya banyak hal yang dilaporkan dalam penelitian ternyata dalam kegiatannya tidak dilaksanakan. 4) Skripsi yang menggunakan metode penelitian kuantitatif, kualitas tinggi terdapat pada unsur judul penelitian, pembatasan masalah, perumusan masalah, metode penelitian, teknik sampling, dan teknik pengumpulan data, serta kesimpulan dan saran. Kualitas sedang dicapai oleh unsur identifikasi masalah, teori, hipotesis, penulisan butir instrumen, teknik analisis data, dan penyajian hasil penelitian. Kualitas rendah terdapat pada unsur latar belakang 
masalah dan kerangka berpikir. 5) Skripsi yang menggunakan metode penelitian kualitatif, kualitas tinggi terdapat pada unsur teori serta kesimpulan dan saran. Kualitas sedang dicapai oleh unsur perumusan masalah, pendekatan penelitian, subjek dan informan penelitian, metode pengumpulan data, pemeriksaan keabsahan data, teknik analisis data dan penyajian hasil penelitian. Kualitas rendah terdapat pada unsur judul penelitian dan latar belakang masalah.

\section{Daftar Pustaka}

Arikunto, Suharsimi. 1995. Dasar-Dasar Evaluasi Pendidikan. Jakarta: Bumi Aksara

Azwar, Saifuddin. 2001. Dasar-Dasar Psikometri. Yogyakarta: Pustaka Pelajar

Echols, John M dan Shadily, Hassan. 2003. Kamus Inggris-Indonesia. Jakarta: Penerbit PT Gramedia

Gerson, Richard F. 2004. Mengukur Kepuasan Pelanggan. Terjemahan Hesty Widyaningrum. Jakarta : Penerbit PPM

Ibrahim, Buddy. 2000. TQM Panduan Untuk Menghadapi Persaiangan Global. Jakarta : Djambatan

Keputusan Presiden Nomor 1 tahun 2011 tentang Alih Status STAIN Surakarta menjadi IAIN Surakarta

Keputusan Presiden Nomor 11 tahun 1997 tentang Alih Status dari Fakultas Daerah IAIN Walisongo di Surakarta menjadi STAIN Surakarta

Kopeuw, Pilipus M. 2012. Evaluasi Penulisan Skripsi Di Perguruan Tinggi Teologi. http:// pealtwo. wordpress. com/ 2012/ 10/09/ evaluasi- penulisan- skripsi- di- perguruan-tinggiteologi/ 
Paine, John; Turner, Philip dan Pryke, Robert. 1992. Total Quality In Education. Sydney: Ashton Scholastic

Purwanto. 2010. Metode Penelitian Kuantitatif. Yogyakarta: Pustaka Pelajar

Purwanto. 2011. Metode Penelitian Kualitatif. Surakarta: Pascasarjana IAIN Surakarta

Sallis, Edward. 2008. Total Quality Management In Education. Terjemahan oleh Ahmad Ali Riyadi dan Fahrurrozi. Yogyakarta: IRCiSoD

Surat Keputusan Menteri Agama Nomor 86 tahun 1992 tentang Relokasi Fakultas Ushuluddin di Kudus dan Fakultas Syari'ah di Pekalongan ke Surakarta

Suryadi, Bambang. 2006. Pentingnya Sistem Penjaminan Mutu PTAI. Makalah disampaikan pada sosialisasi penjaminan mutu di Surabaya

Susanti, Rini. 1997. Evaluasi Skripsi Mahasiswa Pendidikan Sejarah Universitas Lampung. Tesis. Tidak diterbitkan

Weis, Carol H. 1984. Penelitian Untuk Mengevaluasi Efektivitas Program Kemasyarakatan. Terjemahan Abdillah Hanafi dan Mulyadi Guntur Waseso. Surabaya: Usaha Nasional

Winkel, WS. 1996. Psikologi pengajaran. Jakarta: PT Grasindo 